\title{
Disaster Risk Management and Resilience: What Remains Untouched?
}

\author{
Nadeera Ahangama and Raj Prasanna
}

\begin{abstract}
The contemporary generation of Disaster Risk Management (DRM) scholars is increasingly contributing to the ongoing debate on applying resilience in theory and practice. Nevertheless, the theoretical foundations of resilience in the DRM context have not yet been sufficiently validated on empirical grounds. This paper produces a review of literature on the DRM and Resilience concept and recognizes unanswered questions in the body of disaster management and resilience literature. There are several theoretical and empirical research gaps recognized and several future research implications are suggested, in particular, of how disaster resilience is achieved in a multi-stakeholder environment, and how to frame the bounce forward concept in disaster. In order to add value to the context, this paper also elaborates on the research gaps specific to Sri Lanka.
\end{abstract}

Keywords: bounce forward, disasters, disaster risk management, literature review, resilience

\section{Introduction}

Even after several decades of scientific research advancement, human beings are still confronted by the rising rate of the devastating impact of natural disasters. However, most national disaster management policies and practices are still centred on the 'loss reduction model', which let communities remain vulnerable to natural disasters (Bhandari et al. 2010). After the United Nations presented the Hyogo Framework for Action (UNISDR 2005), most research in the area of disaster management has shifted from the 'loss reduction' paradigm to resilience based on disaster management systems (Bhandari et al. 2010, Norris et al. 2008, Aldunce et al. 2014, Klein et al. 2003). While old thinking of "loss reduction" attempts to just prevent damage, resilience focuses on building strong communities that are able to survive

Nadeera Ahangama is a Senior Lecturer of School of Computing, National School of Business Management and a PhD candidate of University of Colombo. Email: nadeera@nsbm.lk (Corresponding author).

Raj Prasanna, $\boldsymbol{P h D}$ is a Senior Lecturer, Joint Centre for Disaster Research, Massey University, New Zealand. 
a disaster and rebound from the impact in a shorter period of time. The concept of resilience is emerging as a paradigm that assists in developing disaster risk management strategies but several research gaps are still evident in this field.

The objective of this paper is to do a comprehensive literature review on disaster risk management, the resilience concept and an amalgamation of the two. First, the paper recognizes current research directions in Disaster Risk Management (DRM), and what areas still require further research. As explained earlier, resilience is a prominent research theme that requires better explanation. Yet a unique definition is required for resilience, particularly in the field of disaster management (Manyena 2006, Cutter et al. 2008, Brand \& Jax 2007, Heazle et al. 2013). Hence, this paper attempts to arrive at a working definition of disaster resilience, followed by recognizing research gaps in the amalgamation of DRM and resilience in the global and Sri Lankan context. It contributes to filling the gap in the literature in using resilience from disaster management perspectives and suggests future research directions.

\section{Defining Disaster Risk Management}

Definitions of disasters in the literature are centred on a few common key aspects. Most disaster scholars recognize a disaster as an 'event' or 'state' which exceeds the capabilities of natural processes (Quarantelli 1988,1998, 2000, Stark \& Erickson 1978, Dorasamy et al. 2013). 'Disaster is a crisis situation that far exceeds the capabilities' states Quarantelly (1988, p. 18). Further, Quarantelly recognizes a disaster as an event in which emergency organizations need to expand and extend themselves in order to cope with the vulnerabilities that arise. Stark and Erickson (1978) explain that a disastrous event has a distinct beginning and a distinct end, resulting from an extraordinary freak of nature, a perversion of the natural processes of life. On the other hand, scholars commonly recognize two inherent properties of a disaster: first, it does a great deal of harm, second, it is sudden, unexpected, acute (Stark \& Erickson 1978, Dorasamy et al. 2013). Dorasamy and the group recognized the following attributes of a disaster: its sudden occurrence, need for quick reactions, the nature of uncertainty, nature of stress, threats to the reputation of organizations, and escalation of intensity.

The World Health Organization (WHO 2002) defined a disaster as 'an occurrence disrupting the normal conditions of existence and causing a level of suffering that exceeds the capacity of adjustment of the affected community'. The United Nations Office for Disaster Risk Reduction (UNISDR 2007) defined disaster as: 
NSBM Journal of Management

Vol. 1, No. 1, January - June, 2015

... A serious disruption of the functioning of a community or a society causing widespread human, material, economic or environmental losses that exceed the ability of the affected community or society to cope using its own resources...

The DRM of man-made disasters and natural disasters has become a prominent theme for research in both the natural and social sciences (Lettieri et al. 2009, Ikeda \& Nagasaka 2011, Scolobig et al. 2015). UNISDR (2007) and the Disaster Management Centre (DMC), Sri Lanka (2005, p. 7)defined DRM as

...The systematic process of using administrative directives, organizations, and operational skills and capacities to implement strategies, policies and improved coping capacities in order to lessen the adverse impacts of hazards and the possibility of disaster...

The next section reviews a collection of DRM literature in order to recognize the research gaps that exist.

\section{Perceptible Gaps in Disaster Management Literature}

Recent DRM research published from 2010 to 2015 (retrieved from online research databases Emerald insight, Springer, Palgrave Macmillan, Science Direct, and Ebsco Host for the keyword 'Disaster Risk Management') is categorized into a few common research themes (Table 1): Decentralization of DRM institutes; Disaster Resilience; Methods, Practices, and Management; Policy and Law; Information Technology Tools for Disaster Management; Instruments to Assess and Indexes; Community Perceptions and Economics.

Decentralization of DRM institutes (Scolobig et al. 2015, Ainuddin et al. 2013, Aldunce et al. 2015, Dixit et al. 2013, Kusumasari et al. 2010, Becker 2012, Ainuddin \& Routray 2012) is a commonly discussed research subject in recent years. Scolobig et al. (2015) examined the transfer of DRM responsibility from the agencies in charge to private citizens, Ainuddin et al. $(2012,2013)$ researched on engagement and coordination among top-down institutional arrangements, Dixit (2013) developed on the initiatives adopted by both governmental and nongovernmental organizations, whereas Kusumasari et al. (2010) and Becker (2012) researched on different local government and other administrative stakeholders' involvement. Many researchers have demonstrated an interest in and recognized the importance of decentralization of DRM institutes, which indicate a recent trend in DRM studies. However, though decentralization of disaster management activities is suggested to be handled by several stakeholders that belong to the bottom-up ladder of the administrative and operational 
hierarchy, most recent research discussions are limited to practical implications rather than theoretical developments. For example, some research done in this respect is limited to how government and non-government multi-level key stakeholders operated during specific disaster events such as the Kashmir 2005 earthquake (Ainuddin \& Routray 2012, Becker 2012, Ainuddin et al. 2013), and the Kathmandu earthquake (Dixit et al. 2013). Hence, more theoretical developments are required to explain the local context in order to understand the holistic framework of DRM among multilevel stakeholders.

\section{Table 1: Research Published (2010 - 2015) in Disaster Risk Management Discipline}

\begin{tabular}{|c|c|c|}
\hline Theme & Research Area & Authors \\
\hline \multirow[t]{7}{*}{$\begin{array}{l}\text { Decentralization of } \\
\text { DRM institutes }\end{array}$} & $\begin{array}{l}\text { Adoption of people-centred approaches, for transfer of DRM } \\
\text { responsibility from the agencies to citizens. }\end{array}$ & (Scolobig et al. 2015) \\
\hline & The decentralization of the disaster management institutions. & (Ainuddin et al. 2013) \\
\hline & $\begin{array}{l}\text { Practitioners' engagement in top-down formal institutional } \\
\text { arrangements. }\end{array}$ & (Aldunce et al. 2015) \\
\hline & $\begin{array}{l}\text { Initiatives adopted by both governmental and } \\
\text { nongovernmental organizations of Nepal to manage } \\
\text { earthquake disaster risks. }\end{array}$ & (Dixit et al. 2013) \\
\hline & $\begin{array}{l}\text { Capability requirements of local government institutions in } \\
\text { pre-, during, and post-disaster activities. }\end{array}$ & (Kusumasari et al. 2010) \\
\hline & $\begin{array}{l}\text { The potential for discrepancies between stakeholders at } \\
\text { different administrative levels in Fiji. }\end{array}$ & (Becker 2012) \\
\hline & $\begin{array}{l}\text { Improving coordination between provincial and national } \\
\text { agencies during disasters and seismic emergencies. }\end{array}$ & $\begin{array}{l}\text { (Ainuddin \& Routray } \\
\text { 2012) }\end{array}$ \\
\hline \multirow[t]{8}{*}{ Disaster Resilience } & $\begin{array}{l}\text { Suggesting a conceptual framework for examining multiple } \\
\text { interpretations of resilience in DRM. }\end{array}$ & $\begin{array}{l}\text { (MacAskill \&Guthrie } \\
\text { 2014) }\end{array}$ \\
\hline & $\begin{array}{l}\text { Practitioners' engagement in the disaster resilience discourse } \\
\text { associated with top-down formal institutional arrangements. }\end{array}$ & (Aldunce et al. 2015) \\
\hline & $\begin{array}{l}\text { Investigate how resilience is framed by researchers and DRM } \\
\text { practitioners. }\end{array}$ & $\begin{array}{l}\text { (Aldunce et al. 2014) } \\
\text { (Folke et al. 2010) }\end{array}$ \\
\hline & Practical guidance methodologies for assessing resilience. & $\begin{array}{l}\text { (Sudmeier-Rieux et al. } \\
\text { 2013) }\end{array}$ \\
\hline & $\begin{array}{l}\text { Posits that resilience should be viewed as the ability to "bounce } \\
\text { forward" rather than "bounce back". }\end{array}$ & $\begin{array}{l}\text { (Manyena et al. 2011) } \\
\text { (Houston 2014) }\end{array}$ \\
\hline & $\begin{array}{l}\text { Systematically analyze the concept of resilience using an } \\
\text { integrated review of literature. }\end{array}$ & $\begin{array}{l}\text { (Garcia-Dia et al. 2013) } \\
\text { (Bhamra et al. 2011) }\end{array}$ \\
\hline & $\begin{array}{l}\text { Enhance the understanding of the multidimensional nature } \\
\text { of resilience for measuring disaster resilience at sub-national } \\
\text { levels. }\end{array}$ & (Burton 2012) \\
\hline & $\begin{array}{l}\text { Development of a preliminary conceptual framework for } \\
\text { assessing community resilience. }\end{array}$ & (Longstaff et al. 2010) \\
\hline
\end{tabular}




\begin{tabular}{|c|c|c|}
\hline Theme & Research Area & Authors \\
\hline \multirow[t]{3}{*}{$\begin{array}{l}\text { Methods, Practices, } \\
\text { and Management }\end{array}$} & $\begin{array}{l}\text { An inquiry into practical solutions in the field of emergent } \\
\text { disaster, rescue methods and prevention management. }\end{array}$ & (Chou \& Chen 2013) \\
\hline & $\begin{array}{l}\text { A greater focus on preparedness through pre-disaster planning } \\
\text { for a more holistic approach to disaster management. }\end{array}$ & (O’Brien et al. 2010) \\
\hline & $\begin{array}{l}\text { Scope for improvement in planning and training, for both } \\
\text { actors and disaster victims, in the front line of disaster } \\
\text { management in Malaysia }\end{array}$ & $\begin{array}{l}\text { (Roosli \& O’Brien } \\
\text { 2011) }\end{array}$ \\
\hline \multirow[t]{4}{*}{ Policy and Law } & DRM law support for vulnerable people. & (Vink \& Takeuchi 2013) \\
\hline & $\begin{array}{l}\text { Disaster risk and disaster management policies and practices } \\
\text { in Pakistan. }\end{array}$ & (Ahmed 2013) \\
\hline & $\begin{array}{l}\text { Policy suggestions for integrating risk management } \\
\text { and increasing risk reduction measures and planning in } \\
\text { Mexico. }\end{array}$ & (Saldana-Zorrilla 2015) \\
\hline & Explore the ethics of disaster management. & (Geale 2012) \\
\hline \multirow[t]{2}{*}{$\begin{array}{l}\text { IT tools for disaster } \\
\text { management }\end{array}$} & $\begin{array}{l}\text { Earth observation, web-based and mobile data management } \\
\text { tools, for disaster risk management. }\end{array}$ & (Dyke et al. 2011) \\
\hline & $\begin{array}{l}\text { Role of an information management system for disaster } \\
\text { management planning. }\end{array}$ & (Islam \& Chik 2011) \\
\hline \multirow[t]{3}{*}{$\begin{array}{l}\text { Instruments to } \\
\text { assess and Indexes }\end{array}$} & $\begin{array}{l}\text { Qualitative instrument for assessing institutional capacity for } \\
\text { early warning and disaster management. }\end{array}$ & $\begin{array}{l}\text { (Fakhruddin \& } \\
\text { Chivakidakarn 2014) }\end{array}$ \\
\hline & Evaluation index of highway flood disaster risk. & (Ou-Yang et al. 2015) \\
\hline & $\begin{array}{l}\text { A methodology for disaster risk management officials to } \\
\text { assess the total disaster risk posed. }\end{array}$ & $\begin{array}{l}\text { (Coetzee \& Van Niekerk } \\
\text { 2013) }\end{array}$ \\
\hline $\begin{array}{l}\text { Community } \\
\text { Perceptions }\end{array}$ & Hazard and risk perception of communities. & (Manen 2014) \\
\hline \multirow[t]{2}{*}{ Economy } & $\begin{array}{l}\text { Extended framework for the analysis of economic effects of } \\
\text { natural disaster risk management. }\end{array}$ & (Chen et al. 2012) \\
\hline & $\begin{array}{l}\text { Understand, manage and reduce the financial and fiscal } \\
\text { impacts of natural disasters. }\end{array}$ & $\begin{array}{l}\text { (Courbage \& Mahul } \\
\text { 2013) }\end{array}$ \\
\hline
\end{tabular}

There is a growing interest in studying the importance of decentralization of disaster management among various government agencies and other stakeholders in recent DRM research (Scolobig et al. 2015, Ainuddin et al. 2013, Ainuddin \& Routray 2012, Aldunce et al. 2015, Dixit et al. 2013, Kusumasari et al. 2010, Becker 2012). Ainuddin et al. (2013) underscored that decentralization of disaster institutions reacted more positively in disaster responses than centralized disaster management procedures. Though most researchers have recognized the importance of decentralized procedures of disaster management from local grassroots level up to the different administrative agency levels in the hierarchy , their researches were limited either to a few specific administrative levels or to very general categories of stakeholders (e.g., sub-national levels (Aldunce et al. 2015, SaldanaZorrilla 2015), governmental and non-governmental organizations (Dixit et al. 2013), local 
and government institutions (Kusumasari et al. 2010, Ahmed 2013), private and public institutions (Desai et al. 2014), and rural district councils (Manyena 2006)). Only a handful of researchers (Becker 2012, Obrist et al. 2010, Ainuddin \& Routray 2012) have considered the contribution of top-bottom multi-level stakeholders to national disaster management.

Lindell (2013) highlighted that disaster literature had not maintained a balance between theoretical and practical sense. The majority of journal papers published between 2010 and 2015 has a practical rather than a theoretical significance (Dixit et al. 2013, Saldana-Zorrilla 2015, Ou-Yang et al. 2015, Courbage \& Mahul 2013, Fakhruddin \& Chivakidakarn 2014, Aldunce et al. 2015, Dyke et al. 2011, Ahmed 2013, Vink \& Takeuchi 2013, Ainuddin et al. 2013, van Manen 2014, Scolobig et al. 2015). Of them, very few papers such as the ones by Chen et al.(2012) and MacAskill and Guthrie (2014) have addressed theoretical aspects of disaster risk management. This is a clear indication of the absence of literature theorizing disaster risk management. On the other hand, Palliyaguru et al. (2014, p.45) argued that, though research on theoretical constructs has a positive effect on understanding the disaster phenomenon, 'the disaster risk management process becomes less effective if theory and practice are set apart from one another'. In their recent book, Lopez-Carresi et al. (2013) recognized that the gap between theory and practice among academia and practitioners in the field of disaster management still exists.

Many practitioners as well as theorists have commonly recognized the new face of DRM research, namely, 'resilience', and it has become a key area of DRM focus in recent years (Burton 2012, Heazle et al. 2013, MacAskill \& Guthrie 2014, Manyena 2006, Mayunga 2007, Sudmeier-Rieux et al. 2013, Aldunce et al. 2015, Norris et al. 2008, Aldunce et al. 2014, Klein et al. 2003, Aldrich 2011). Despite its prominence and acceptability as a key global policy of practice (Hyogo Framework for Action 2005 by the United Nations) (UNISDR 2005), many researchers believe that the resilience concept still requires theoretical and practical development. For example, Mayunga (2007) recognized that there is limited theoretical understanding of the resilience concept. Bhamra et al. (2011) argued that for the resilience theory to create value in the real world, more real world-based empirical research needs to be done to validate the theoretical constructs. Brown (2011) also contended that resilience theory is limited in conceptualization while ambiguity remains in regard to its applicability within the practice of DRM. MacAskill and Guthrie (2014) reasoned that as a guiding principle, the resilience concept is context-dependent and still needs elucidation. Hence, it is necessary to clarify how DRM and resilience concepts are practically operationalized and how theoretical understanding helps to bring balance in the literature. 


\section{NSBM Journal of Management}

Vol. 1, No. 1, January - June, 2015

DRM research published between 2010 and 2015 (Table 2) indicate variations in maturity of research themes. For instance, methods, practices, and management themes of disaster researches reveal maturity in their area and discussion is more narrowed down, precise and clear-cut in research topics like disaster rescue methods (Chou \& Chen 2013), pre-disaster planning for a holistic approach (O’Brien et al. 2010), and improvement in planning and training (Roosli \& O'Brien 2011). Policy, law, instruments of assessment, indices and research themes also signify the maturity of the research area. For example, policy development in specific regions (Ahmed 2013, Saldana-Zorrilla 2015), ethics of disaster management (Geale 2012), indices and assessment to evaluate disaster capacity and risk (Fakhruddin \& Chivakidakarn 2014, Ou-Yang et al. 2015, Coetzee \& Van Niekerk 2013), and economic effects (Chen et al. 2012, Courbage \& Mahul 2013). In contrast, most resilience research is still looking at how to frame or define the concept of disaster resilience, for example, framing resilience (MacAskill \& Guthrie 2014, Aldunce et al. 2014, Folke et al. 2010, Manyena et al. 2011, Houston 2014, Garcia-Dia et al. 2013, Bhamra et al. 2011), forming of resilience frameworks (Longstaff et al. 2010), and practical guidance methodologies for assessing resilience (Sudmeier-Rieux et al. 2013) etc. Hence, this indicates a need for more in-depth research to establish the resilience concept in disaster management and further research on conceptualization of a multi-institutional disaster resilience framework, especially in the local need for a holistic framework for bulilding national disaster resilience. On the other hand, the concept of resilience had a presence in the research arena for several decades, but the definition remains contested in literature (Manyena 2006, Cutter et al. 2008, Brand \& Jax 2007, Heazle et al. 2013). Irrespective of the roots of the resilience, Norris et al. (2008) argued that the resilience concept is applied in various fields and have multiple definitions. Few researchers have illustrated the evolution of the resilience concept and outlined the diversity of definitions in various disciplines in recent years (Aldunce et al. 2014, Norris et al. 2008, Bhamra et al. 2011, Garcia-Dia et al. 2013). Still a disaster resilience definition requires refining. The next section, attempts to arrive at a working definition of disaster resilience.

\section{Defining Disaster Resilience}

Most definitions of resilience commonly include the following themes: ability to bounce back (Norris et al. 2008, Paton et al. 2001), without being deformed (Gordon 1980), the speed at which the system returns to normalcy after a hazard (Bodin \& Wiman 2004), measure of the ability to absorb the change (Holling 1973), continue existence/persistence (Holling 1973, Longstaff 2005), strengthen community bonds, resources and the community's capacity to cope (Chenoweth \& Stehlik 2001), to take meaningful, deliberate, collective action to minimize the impact (Pfefferbaum et al. 2007), and find unknown inner strengths and 
resources (Ganor \& Ben-Lavy, 2003). Pfefferbaum et al (2007) believed that resilience is better conceptualized as an ability or process.

Resilience definitions in the ecological literature are of two kinds both of which reflect the stability of systems (Gunderson 2000). Holling (1973) argued that the behaviour of ecological systems could be explained using two dissimilar properties: resilience and stability. The pioneering work of Holling (1973, p.17) in resilience in ecosystems defined resilience as 'the persistence of relationships within a system and is a measure of the ability of these systems to absorb changes of state variables, driving variables, and parameters, and still persist.' On the other hand, Holling (p. 17) characterized stability as persistence of a system near or close to an equilibrium state (Gunderson 2000, Ives 1995). This indicates that stability is the 'ability of a system to return to an equilibrium state after a temporary disturbance' (Holling 1973, p. 17). Hence, a measure of resilience is how far the system has moved from equilibrium (in time) and how quickly it returns (ibid). Some scholars in the field of physics field defined resilience as 'the ability to store strain energy and deflect elastically under a load without breaking or being deformed (Gordon 1980 cited in Aldunce et al 2014). In contrast to this view, engineering literature indicates resilience as the behaviour of dynamic systems far from equilibrium, and it is measured by the return time as a measure of stability (Holling 1973, Gunderson 2000). Holling (1973) called this 'engineering resilience'.

As Gunderson (2000, p.435) further explained, the return time definition evolved from engineering traditions, i.e., in the engineering system perspective, 'return time to a single, global equilibrium'. However, ecological resilience is postulated in the existence of multiple equilibriums or multiple stable states which facilitate transition among stable states (Holling 1973, Gunderson 2000). Hence, ecological resilience is seen as the width or limit of a stability domain and is defined by the magnitude of disturbance that a system can absorb before it redefines system structure by changing its stable states through modifying variables and processes that can control behaviour (Holling 1973, Gunderson 2000, Ludwig et al. 1997). Additionally, Gunderson (2000) believed that the processes that contribute to system 'memory' of those involved could restore ecological resilience. Other fields of study which embrace the concept of resilience are psychology, community studies, and disaster management. Table 2 gives a list of selected resilience definitions in various disciplines from 2000 to 2014 .

Transversely, these definitions have little general consensus. First, resilience is recognized as a process rather than an outcome (Gunderson 2000, Pfefferbaum et al. 2007, Norris et al. 2008, Besser 2013, Houston et al. 2014). Secondly, resilience is defined as the capacity or 
NSBM Journal of Management

Vol. 1, No. 1, January - June, 2015

ability to absorb disturbances and/or bounce back/return from adverse situations to normalcy (Gunderson 2000, Paton et al. 2001, Klein et al. 2003, Walker et al. 2004, Folke et al. 2010, Longstaff et al. 2010, Garcia-Dia et al. 2013). Thirdly, resilience is better theorized as adaptability than as stability. At the start of the time line from year 2000, Gunderson (2000) recognized resilince as the level of stability of a system which can absorb disturbances. However, most later definitions conceptualize resilience as adaptability or capacity to cope (Chenoweth \& Stehlik 2001, Ganor \& Ben-Lavy 2003, Pfefferbaum et al. 2007, Norris et al. 2008, Houston et al. 2014).

Table 2: Some Recent Definitions of Resilience (Year 2000 - 2015)

\begin{tabular}{|c|c|c|}
\hline Field & Author(s) & Definition \\
\hline $\begin{array}{l}\text { Ecology } \\
\text { A }\end{array}$ & (Gunderson 2000) & $\begin{array}{l}\text { Width or limit of a stability domain and defined by the magnitude } \\
\text { of disturbance that a system can absorb before it redefines system } \\
\text { structure by changing its stable states through modifying variables } \\
\text { and processes that can control behaviour. }\end{array}$ \\
\hline $\begin{array}{l}\text { Community } \\
\text { Studies } \\
\text { C }\end{array}$ & $\begin{array}{l}\text { (Chenoweth \& } \\
\text { Stehlik 2001) }\end{array}$ & $\begin{array}{l}\text { Communities can be considered as being resilient when they respond } \\
\text { to crises in ways that strengthen community bonds, resources and the } \\
\text { community's capacity to cope. }\end{array}$ \\
\hline $\begin{array}{l}\text { Disaster } \\
\text { Management } \\
\text { D }\end{array}$ & (Paton et al. 2001) & $\begin{array}{l}\text { The capability to bounce back and to use physical and economic } \\
\text { resources effectively to aid recovery following exposure to hazards }\end{array}$ \\
\hline $\begin{array}{l}\text { Disaster } \\
\text { Management } \\
\text { D }\end{array}$ & (Klein et al. 2003) & $\begin{array}{l}\text { Resilience is the amount of disturbance a system can absorb and still } \\
\text { remain within the same state or domain of attraction and the degree } \\
\text { to which the system is capable of self- organization. }\end{array}$ \\
\hline $\begin{array}{l}\text { Community } \\
\text { Studies and } \\
\text { Disaster } \\
\text { Management } \\
\text { D }\end{array}$ & $\begin{array}{l}\text { (Ganor \& Ben-Lavy } \\
\text { 2003) }\end{array}$ & $\begin{array}{l}\text { 'The ability of individuals and communities to deal with a state } \\
\text { of continuous, long term stress; the ability to find unknown inner } \\
\text { strengths and resources in order to cope effectively; the measure of } \\
\text { adaptation and flexibility' (p. 106) }\end{array}$ \\
\hline \multirow[t]{2}{*}{$\begin{array}{l}\text { Ecology and } \\
\text { Engineering } \\
\text { A, B }\end{array}$} & $\begin{array}{l}\text { (Bodin \&Wiman } \\
\text { 2004) }\end{array}$ & $\begin{array}{l}\text { 'The dynamic behaviour of the system as it strives (if at all) to return } \\
\text { to equilibrium, i.e., the extent to which and the speed with which } \\
\text { return occurs' (p. 34) }\end{array}$ \\
\hline & & $\begin{array}{l}\text { *Bodin \& Wiman believed that one ought to get back to the original } \\
\text { definitions of stability and diversity in mathematics into ecology. }\end{array}$ \\
\hline $\begin{array}{l}\text { Ecology } \\
\text { A }\end{array}$ & $\begin{array}{l}\text { (Walker et al. 2004) } \\
\text { (Folke et al. 2010) }\end{array}$ & $\begin{array}{l}\text { 'Resilience is the capacity of a system to absorb disturbance and } \\
\text { reorganize while undergoing change so as to still retain essentially } \\
\text { the same function, structure, identity, and feedback - in other words, } \\
\text { stay in the same basin of attraction.' (p. 11) }\end{array}$ \\
\hline $\begin{array}{l}\text { Psychiatrics } \\
\text { C }\end{array}$ & $\begin{array}{l}\text { (Pfefferbaum et al. } \\
\text { 2007) }\end{array}$ & $\begin{array}{l}\text { The ability of community members to take meaningful, deliberate, } \\
\text { collective action to remedy the impact of a problem, including the } \\
\text { ability to interpret the environment, intervene, and move on. }\end{array}$ \\
\hline $\begin{array}{l}\text { Community } \\
\text { Studies } \\
\text { C }\end{array}$ & (Norris et al. 2008) & $\begin{array}{l}\text { 'A process linking a set of adaptive capacities to a positive trajectory } \\
\text { of functioning and adaptation after a disturbance' (p. 130) }\end{array}$ \\
\hline $\begin{array}{l}\text { Community } \\
\text { Studies } \\
\text { C }\end{array}$ & $\begin{array}{l}\text { (Longstaff et al. } \\
\text { 2010) }\end{array}$ & $\begin{array}{l}\text { 'The capacity of a system to absorb disturbance, undergo change, and } \\
\text { retain the same essential functions, structure, identity, and feedback' } \\
\text { (p. 3) }\end{array}$ \\
\hline
\end{tabular}




\begin{tabular}{|c|c|c|}
\hline Field & Author(s) & Definition \\
\hline $\begin{array}{l}\text { Community } \\
\text { Studies } \\
\text { C }\end{array}$ & (Besser 2013) & $\begin{array}{l}\text { Resilient communities are 'those that maintain or enhance residents' } \\
\text { quality of life following a shock' (p. 117) }\end{array}$ \\
\hline $\begin{array}{l}\text { Psychiatrics } \\
\text { C }\end{array}$ & $\begin{array}{l}\text { (Garcia-Dia et al. } \\
\text { 2013) }\end{array}$ & $\begin{array}{l}\text { Resilience is one's ability to bounce back or recover from adversity' } \\
\text { (p.267) }\end{array}$ \\
\hline $\begin{array}{l}\text { Community } \\
\text { Studies and } \\
\text { Disaster } \\
\text { Management } \\
\text { D }\end{array}$ & (Houston et al. 2014) & $\begin{array}{l}\text { 'A community is resilient if it is able to "bounce forward" after } \\
\text { an adverse event. Community resilience is generally considered } \\
\text { a process that is indicated by community adaptation following a } \\
\text { disaster or crisis.' (p. 270) }\end{array}$ \\
\hline
\end{tabular}

While the engineering field defined resilience in the temporal domain (categorized as type B in Table 2), i.e., the speed at which the system arrives at the equilibrium after a disturbance occurs (Bodin \& Wiman 2004), the field of ecology views resilience mostly in the spatial domain (categorized as Type A in Table 2). Scholars from the ecology field defined resilience as the extent to which a system can absorb disturbances (Gunderson 2000, Walker et al. 2004, Folke et al. 2010). In ecological settings, resilience has been used interchangeably in conjunction with the concept of 'adaptation' of climate studies (Joerin et al. 2014). In contrast, community studies and psychiatrics have suggested more social and/or psychological aspects in resilience while building on the capacity to adopt/cope as in ecological definitions (Chenoweth \& Stehlik 2001, Ganor \& Ben-Lavy 2003, Longstaff et al. 2010, Besser 2013) (categorized as Type $\mathrm{C}$ in Table 2).

On the other hand, resilience definitions in the field of disaster management closely coincide with definitions in community studies because disaster management studies are also specific about the capacity to adopt/cope (categorized as Type D in Table 2). For example, Chenoweth and Stehlik (2001) recognized resilience as the community's capacity to cope when responding to crises. Chenoweth and Stehlik are also specific about the ways in which resilience shall be enforced, i.e., strengthening community bonds and resources. Other disaster management scholars have suggested the following aspects in their definitions: efficient use of physical and economic resources (Paton et al. 2001, Ganor \& Ben-Lavy 2003), ability to self-organize (Klein et al. 2003), ability to find unknown inner strengths (Ganor \& Ben-Lavy 2003), and maintain or enhance residents' quality of life (Besser 2013).

While early researchers theorized resilience as 'bounce back' (Gordon 1980, Paton et al. 2001, Bodin \& Wiman 2004, Tugade \& Fredrickson 2004, Garcia-Dia et al. 2013), some recent research defines resilience as 'bounce forward' ability (Manyena et al. 2011, Houston et al. 2014). As Manyena et al. (2011, p. 243) stated, resilience as 'the notion of bounce 
forward is to see disaster as an opportunity for local livelihood enhancement rather than as a simple return to the status quo ante'. As they further describe, resilience should be perceived as the ability to 'bounce forward' and 'move on' following a disaster rather than 'bounce back' and move to community status before the occurrence of disaster. Taking several examples, such as how Japan's 2011 earthquake and the subsequent tsunami and total destruction of the Fukushima nuclear power plant led other countries to rethink their power-generation strategies, Manyena et al (2011) suggested that resilience is not simply 'bounce back' but 'bounce forward', considering that a disaster as an opportunity to change. Paton and Johnston (2006) highlighted the gaps in the existing resilience definitions with the concept of 'bounce back'. As they further explained, 'bouncing back' does not portray the changed reality and new opportunities formed due to a disaster. Such change assists in pre-disaster planning by adjusting to new post-disaster realities (Manyena et al. 2011). Explaining further, Paton and Johnson (2006) explained that even though affected community wants to return to the previous state, changes to the physical, social and psychological reality make bounce back unfeasible. Hence, this paper defines disaster resilience as 'the capacity of a system to adopt to the adversity of a disaster and bounce forward strengthening community bonds, and resources'. The next section recognizes the research gaps in the amalgamation of DRM and resilience.

\section{Disaster Risk Management and Resilience: What is unanswered?}

MacAskill and Guthrie (2014, p. 667) stated that resilience has 'emerged as a guiding principle' in DRM. However, there are several unanswered queries relating to disaster management and resilience and the link between them. Lettieri et al. (2009) pointed out that most literature on disaster management theory commonly agrees on a common theoretical framework which is independent of the type of disaster. However, most such frameworks focus on technical issues and neglect the contributions from the organizational and psychological fields, thus leading to difficulties in making these frameworks actionable (Lettieri et al. 2009). Though termed differently, most literature commonly agree that a systematic disaster management process framework has three temporal and logical stages: pre-disaster, response, and postdisaster (Todd \& Todd 2011, Lettieri et al. 2009, Lindell 2013, Mansor et al. 2004). These phases do not have global acceptance and their functions are not mutually exclusive and such functions may overlap in the temporal and logical space (Lindell 2013). This obviously would make recognition of the importance of resilience in disaster management problematic. As MacAskill and Guthrie (2014, p. 673) explained, this ambiguity 'is likely to be a factor as to why there are differences between academic or theoretical conceptions of resilience and application of the concept in practice'. Also, there is no research evidence to explain 
how resilience is operationalized in each stage of the disaster management cycle. Hence, it indicates that scholarly work done so far has paid little attention to explaining how to embed the process of resilience in the disaster management cycle.

Another common research gap which many researchers have recognized is the absence of empirical validation of different aspects of resilience theory. For example, Bhamra et al. (2011, p. 5388) pointed out that 'there appears to be a strong focus around building theories and definitions of resilience', but there are very little empirical research done to understand how organisations can attain resilience in the face of disasters. Sudmeier-Rieux et al.(2013) also recognized that there is an empirical limitation in practical guidance methodologies for assessing resilience. Brown (2011) argued that though DRM practitioners and policy makers frequently include the concept of resilience in policy documents, such inclusions are not based on theoretical or empirical groundings. Manyena et al (2011) and Paton and Johnson (2006) suggested that disaster resilience is associated with bouncing forward rather than bouncing back. Empirical evidence of resilience as a bouncing forward process is significantly limited. Janssen et al. (2006) argued that comparing case studies on resilience assessment of regional social-ecological systems is difficult because they do not follow the guidance of a resilience framework on structural changes. The next section throws light on research evidence and gaps that can be especially found in the Sri Lankan context.

\section{Disaster Risk Management and Resilience from the Lens of Sri Lanka}

The widespread disaster caused by the Tsunami (2004) in Sri Lanka reconfirmed the crucial requirement of 'multi-sectorial, inter-institutional, and multi-disciplinary' mechanisms to handle disasters in the country (Disaster Management Centre, 2005). On these grounds several interim committees, legislative (Sri Lanka Disaster Management Act No. 13 of 2005) and institutional arrangements (DMC-Disaster Management Centre, MODM-Ministry of Disaster Management) were established. In parallel to this development, scholars have been increasingly contributing to DRM and resilience literature in recent years.

The research done in the context of Sri Lanka is developed in three knowledge domains: disaster mitigation and preparedness (Jayamanna 2008, Mudalige 2011, Yoshitani et al. 2007, Wickramaratne et al. 2012, Minamoto 2010); DRM plans and policies (Ranasinghe 2011); and disaster resilience (Senanayake \& Barthelot 2013, Somasundaram \& Sivayokan 2013, Hettiarachchi et al. 2014, Malalgoda et al. 2013, Pathirage et al. 2012, Ingirige et al. 2008, Thanurjan \& Seneviratne 2009). 


\section{NSBM Journal of Management}

Vol. 1, No. 1, January - June, 2015

Several researchers focused their work on disaster mitigation and preparedness. For example, Jayamanna (2008) provided a case study on flood mitigation and preparedness in the Kalutara Urban Council area, illustrating the significance of actions by various stakeholders including community members. Mudalige (2011) explored the flood management systems in Sri Lanka and recognized that Sri Lanka still lacked a real time flood early warning system (Yoshitani et al. 2007). Yoshitani et al. (2007) also focused on Sri Lanka's natural and social characteristics and risks associated with water-related disasters. Wickramaratne et al. (2012) proposed a methodology for a priori classification of natural disasters that occur in Sri Lanka to support preparing mitigation plans. A survey of 187 households in eastern Sri Lanka that suffered from the 2004 Indian Ocean tsunami recognized that linking social capital between survivors and national and international nongovernmental organizations (NGOs) was critical in rebuilding Minamoto (2010). Most research on disaster preparedness and mitigation in Sri Lanka is based on a single location. A cross-sectional view and comparison between locations would add strength to explaining disaster preparedness and mitigation in Sri Lanka. Also, there is no sufficient research to assess or evaluate current DRM mitigation plans within Sri Lanka.

Only a few researches have focused on DMR plans and policies in Sri Lanka. Ranasinghe (2011) provided plausible suggestions to mainstream disaster risk reduction in policies, programmes and plans in Sri Lanka to build resilient cities. She suggested zoning of the areas according to the land capability, conservation, having building codes, having green belts, green lungs in cities, installation of early warning systems, and improving disaster awareness among the community as imperative for resilience in cities. However, it is noted that most DRM plans and policies are still focused on loss reduction models. Still the concept of resilience has not been included in DRM policy research.

A growing interest is seen among scholars to contribute to empirical literature on disaster resilience knowledge in Sri Lanka. For example, Senanayake and Barthelot (2013) focused on the use of children as change agents to collect and disseminate grass root level flood information using participatory flood mapping techniques and improve the awareness of the community on flood resilience in Batticaloa city, Sri Lanka. They suggested that children acted as change agents within the system to facilitate bottom-up as well as top-bottom information flows in the neighborhood. Ingirige et al. (2008) focused on how knowledge transfer impacts the effective and efficient delivery of post-tsunami housing in Sri Lanka. They found that knowledge transfer within this context requires knowledge localization. Therefore, Ingirige et al. (2008) suggested community engagement through participatory techniques among various stakeholders for innovation. Thanurjan and Seneviratne (2009) examined the degree to which 
knowledge management is used in post-disaster housing reconstruction in Sri Lanka. Their study revealed that organizations use competences and repositories as the main sources of knowledge, internal and external to the organization. Somasundaram and Sivayokan (2013) focused their research on understanding common psychosocial problems faced by families and communities in the context of rebuilding community resilience in post-war times. Since community members were significantly affected by post trauma experiences, they suggested the use of cultural practices and awareness programmes to revitalize resilience. A joint case study presented by the University of Salford and DMC Sri Lanka (2012) focused on providing a snapshot of local level resilience building activities associated with the city of Batticaloa. The case study identified trends in the perceptions and approaches of local governments toward disaster risk reduction. Hettiarachchi et al. (2014) studied the nature and extent of degradation in a selected segment of the Colombo Flood Detention Area (CFDA) wetlands and disaster resilience. They analyzed the gradual process of change in watersheds and the wetland ecology affecting flood control services. It was found that gradual ecological change in this area leads to a significant reduction in the water-holding capacity of the wetlands, thus increasing the frequency of floods.

A handful of researchers promoted literature connecting knowledge transfer and disaster resilience in the context of Sri Lanka. For example, Malalgoda et al (2013)explored the role and challenges for Sri Lankan local governments in creating a disaster-resilient builtenvironment within Batticaloa city of Sri Lanka. Their study revealed that local governments are facing a considerable challenge due to the lack of knowledge of disaster risks and vulnerabilities. Hence, further research in this area is highly recommended in the local context. Even though the resilient concept is not directly addressed, Pathirage et al (2012) examined key knowledge factors related to the disaster management cycle and explored the challenges associated with them. However, these researches have not managed to build sufficient empirical evidence of how knowledge can be efficiently transferred to develop disaster resilience longitudinally. Also, most of researches of the above scholars in the local ground consider resilience as a part of DRM, but there has been very little focus on the theoretical development of resilience.

\section{Conclusion}

In conclusion, the authors suggest several future research directions blending DRM and resilience. There is a theoretical and empirical gap in how disaster resilience is achieved in a multi-stakeholder environment. In particular, the Disaster Management Centre in Sri Lanka has formalized a multi-stakeholder framework for DRM. However, that initiative has 


\section{NSBM Journal of Management}

Vol. 1, No. 1, January - June, 2015

not yet been completely assessed theoretically or practically and also the resilience concept is hardly embedded in it. This indicates that resilience studies should be further directed to study how structural components (nodes and links) are arranged over time and how various network characteristics such as connectivity and centrality operate in dynamic situations. Another research gap in the DRM literature is the imbalance between the theoretical and practical sense. The majority of DRM literature is practical-based and little importance is given to theoretical developments. On the other hand, the resilience concept still requires theoretical as well as practical development. Resilience still appears to be at an initial stage where researchers still attempt to frame it in a DRM context. Hence, this indicates a need for more in-depth research to establish the resilience concept for conceptualization of a multi-institutional disaster resilience framework, especially in the local need for a holistic framework for building national disaster resilience. Another area that needs further research is the concept of 'bounce forward'. Most recent research is limited to evaluating empirical grounds for 'bouncing back'. But further research should be conducted to understand how a disaster functions as an opportunity for change and further improvement. Another research gap is the absence of research evidence to explain how resilience is operationalized in each stage of the disaster management cycle. So, further research is needed to explain how to embed the process of resilience in the disaster management cycle.

\section{References}

Ahmed, Z 2013, 'Disaster risks and disaster management policies and practices in Pakistan: A critical analysis of Disaster Management Act 2010 of Pakistan', International Journal of Disaster Risk Reduction, vol.4, pp.15-20.

Ainuddin, S, Aldrich, DP, Routray, JK \& Achkazai, A 2013, 'The need for local involvement: decentralization of disaster management institutions in Baluchistan, Pakistan', International Journal of Disaster Risk Reduction, vol. 6, pp.50-58.

Ainuddin, S \& Routray, JK 2012, 'Institutional framework, key stakeholders and community preparedness for earthquake induced disaster management in Balochistan', Disaster Prevention and Management, vol. 21, pp.22-36.

Aldrich, DP 2011, 'The Externalities of Strong Social Capital: post-tsunami recovery in Southeast India', Journal of Civil Society, vol. 7, pp.81-99.

Aldunce, P, Beilin, R, Handmer, J \& Howden, M 2014, 'Framing disaster resilience: the implications of the diverse conceptualisations of "bouncing back", Disaster Prevention and Management, vol 23, pp.252-270.

Aldunce, P, Beilin, R, Howden, M \& Handmer, J. 2015, 'Resilience for disaster risk management in a changing climate: practitioners' frames and practices', Global Environmental Change, vol 30, pp.1-11. 
Becker, P 2012, 'The importance of integrating multiple administrative levels in capacity assessment for disaster risk reduction and climate change adaptation', Disaster Prevention and Management, vol 21, pp.226-233.

Besser, T 2013, 'Resilient small rural towns and community shocks', Journal of Rural and Community Development, vol. 8, no. 1, pp.117-134.

Bhamra, R, Dani, S \& Burnard, K 2011 ,'Resilience: the concept, a literature review and future directions', International Journal of Production Research, vol. 49, no. 18, pp. 5375-5393.

Bhandari, RB, Norio, O, Yokomatsu, M \& Ikeo, H 2010, 'Building a disaster resilient community through ritural based social capital: a brief analysis of findings from the case study of Kishiwada', Annuals of Disaster Prevention Resources Institute, no. 53.

Bodin, P \& Wiman, BLB 2004, 'Resilience and other stability concepts in ecology : notes on their origin, validity', ESS Bulletin, vol. 2, pp. 33-43.

Brand, FS \& Jax, K 2007, 'Focusing the meaning(s) of resilience: Resilience as a descriptive concept and a boundary object', Ecology and Society, vol. 12.

Brown, K 2011, 'Policy discourses of resilience',Climate change and the crisis of capitalism: a chance to reclaim, self, society and nature, Routledge, London, pp. 37-50.

Burton, CG 2012, The development of metrics for community resilience to natural disasters, $\mathrm{PhD}$ thesis,University of South Carolina.

Chen, CW, Tseng, CP, Hsu, WK \& Chiang, W 2012, 'A novel strategy to determine the insurance and risk control plan for natural disaster risk management', Natural Hazards, vol. 64, pp.1391-1403.

Chenoweth, L \& Stehlik, D 2001, 'Building resilient communities: social work practice and rural Queensland', Australian Social Work, vol. 54, pp.47-54.

Chou, SY \& Chen, D 2013, 'Emergent disaster rescue methods and prevention management', Disaster Prevention and Management, vol. 22, pp.265-277.

Coetzee, C \& Van Niekerk, D 2013, 'Towards a disaster risk assesment methodology for communities underlain by dolomite', Disaster Prevention and Management, vol. 22, p.5.

Courbage, C \& Mahul, O 2013, 'Promoting better understanding on sustainable disaster risk management strategies', The Geneva Papers on Risk and Insurance Issues and Practice, vol. 38, no. 3, pp.401-405.

Cutter, SL, Barnes, L, Berry, M, Burton, C, Evans, E \& Tate, E 2008, 'A place-based model for understanding community resilience to natural disasters', Global Environmental Change, vol. 18, pp.598-606.

Desai, B, Bell, PC \& Sarmiento, JP 2014, 'Special issue: risking disaster-The role of private investment and public regulation in disaster risk management', International Journal of Disaster Risk Reduction, pp.1-2.

Disaster Management Center (DMC) 2005, Towards a Safer Sri Lanka A Road Map for Disaster Risk Management, viewed 05 December 2014, http://www.dmc.gov.lk/Publications/Road_Map_Volume_2. pdf. 


\section{NSBM Journal of Management}

Vol. 1, No. 1, January - June, 2015

Dixit, AM, Yatabe, R, Dahal, RK \& Bhandary, NP 2013, 'Initiatives for earthquake disaster risk management in the Kathmandu Valley', Natural Hazards, vol. 69, pp.631-654.

Dorasamy, M, Raman, M \& Kaliannan, M 2013, 'Knowledge management systems in support of disasters management: A two decade review', Technological Forecasting and Social Change, vol. 80, pp.1834-1853.

Dyke, G, Gill, S, Davies, R, Betorz, F, Andalsvik, Y, Cackler, J, Dos Santos, W, Dunlop, K, Ferreira, I, Kebe, F, Lamboglia, E, Matsubara, Y, Nikolaidis, V, Ostoja-Starzewski, S, Sakita, M \& Verstappen, N 2011, 'Dream project: applications of earth observations to disaster risk management', Acta Astronautica, vol. 68, no. 1-2, pp.301-315.

Fakhruddin, SHM \& Chivakidakarn, Y 2014, 'A case study for early warning and disaster management in Thailand', International Journal of Disaster Risk Reduction, vol. 9, pp.159-180.

Folke, C, Carpenter, SR, Walker, B, Scheffer, M, Chapin, T \& Rockström, J 2010, 'Resilience thinking: Integrating resilience, adaptability and transformability', Ecology and Society, vol. 15, viewed 7 December 2014, http://www.fs.fed.us/pnw/pubs/journals/pnw_2010_folke.pdf

Ganor, M \& Ben-Lavy, Y 2003, 'Community resilience: lessons derived from gilo under fire', Journal of Jewish Communal Service, vol. 79, pp.105-108.

Garcia-Dia, MJ, DiNapoli, JM, Garcia-Ona, L, Jakubowski, R \& O'Flaherty, D 2013, 'Concept Analysis: Resilience', Archives of Psychiatric Nursing, vol. 27, no. 6, pp.264-270.

Geale, SK 2012, 'The ethics of disaster management', Disaster Prevention and Management, vol. 21, pp.445-462.

Gordon, JE 1980, 'Structures, or why things don't fall down', American Journal of Physics, vol. 48, p.787.

Gunderson, LH 2000, Ecological Resilience - In theory and application. Annu. Rev. Ecol. Syst. 2000. 31:, 31, pp. 425-39.

Heazle, M, Tangney, P, Burton, P, Howes, M, Grant-Smith, D, Reis, K \& Bosomworth, K 2013, 'Mainstreaming climate change adaptation: An incremental approach to disaster risk management in Australia', Environmental Science \& Policy, vol. 33, pp.162-170.

Hettiarachchi, M, Athukorale, K, Wijekoon, S \& de Alwis, A 2014, 'Urban wetlands and disaster resilience of Colombo, Sri Lanka', International Journal of Disaster Resilience in the Built Environment, vol. 5, no. 1, pp.79-89.

Holling, CS 1973, 'Resilience and stability of ecological systems', Annual Review of Ecology and Systematics, vol. 4, pp.1-23.

Houston, JB 2014, 'Bouncing forward: assessing advances in community resilience assessment, intervention, and theory to guide future work', American Behavioral Scientist, vol. 59, pp.175-180.

Houston, JB, Spialek, M L, Cox, J, Greenwood, M M \& First, J. 2014, 'The centrality of communication and media in fostering community resilience: a framework for assessment and intervention', American Behavioral Scientist, vol. 59, pp.270-283. 
Ikeda, S \& Nagasaka, T 2011, 'An emergent framework of disaster risk governance towards innovating coping capability for reducing disaster risks in local communities', International Journal of Disaster Risk Science, vol. 2, pp.1-9.

Ingirige, B, Haigh, R, Malalgoda, C \& Palliyaguru, R 2008, 'Exploring good practice knowledge transfer related to post-tsunami housing (re-) construction in Sri Lanka', Construction, vol. 13, no. 2, pp. $21-42$.

Islam, SMT \& Chik, Z 2011, 'Disaster in Bangladesh and management with advanced information system', Disaster Prevention and Management, vol. 20, pp.521-530.

Ives, AR 1995, 'Measuring resilience in stochastic systems', Ecological Monographs, vol. 65, pp.217233.

Janssen, MA, Bodin, Ö, Anderies, JM, Elmqvist, T, Ernstson, H, McAllister, RRJ, Olsson, P \& Ryan, P 2006, 'Toward a network perspective of the study of resilience in social-ecological systems', Ecology and Society, vol. 11, p.15.

Jayamanna, M 2008, Urban flood risk mitigation in Kalutara city, Sri Lanka, viewed 10 December 2014, http://www.adpc.net/igo/category/ID222/doc/2013-qv18PC-ADPC-Safer_Cities_23.pdf.

Joerin, J, Shaw, R, Takeuchi, Y \& Krishnamurthy, R 2014, 'The adoption of a climate disaster resilience index in Chennai, India', Disasters, vol. 38, no. 3, pp.540-561.

Klein, RJT, Nicholls, RJ \& Thomalla, F 2003, 'Resilience to natural hazards: How useful is this concept?', Environmental Hazards, vol. 5, pp.35-45.

Kusumasari, B, Alam, Q \& Siddiqui, K 2010,'Resource capability for local government in managing disaster', Disaster Prevention and Management, vol. 19, pp.438-451.

Lettieri, E, Masella, C \& Radaelli, G 2009, 'Disaster management: findings from a systematic review', Disaster Prevention and Management, vol. 18, no. 2, pp.117-136.

Lindell, MK 2013, 'Disaster studies', Current Sociology Review, vol. 61, no. 5-6, pp.797-825.

Longstaff, PH, Armstrong, N, Perrin, K, Parker, WM \& Hidek, MA 2010,'Building resilient communities: a preliminary framework for assessment', Homeland Security Affairs, vol. 4, pp.1-23.

Longstaff, P H 2005, 'Security, resilience and communication in unpredictable environments such as terrorism, natural disasters and complex technology'.

Lopez-Carresi, A, Fordham, M, Wisner, B, Kelman, I \& Gaillard, JC 2013, Disaster management: international lessons in risk reduction, response and recovery, Earthscan LLC.

Ludwig, D, Walker, B \& Holling, CS 1997, 'Sustainability, stability, and resilience', Ecology and Society, vol. 1, no. 1, viewed 30 December 2014, http://www.ecologyandsociety.org/vol1/iss1/art7.

MacAskill, K \& Guthrie, P 2014, 'Multiple interpretations of resilience in disaster risk management' Procedia Economics and Finance, vol. 18, no. September, pp.667-674.

Malalgoda, C, Amaratunga, D \& Haigh, R 2013, 'Creating a disaster resilient built environment in urban cities: The role of local governments in Sri Lanka', International Journal of Disaster Resilience in the Built Environment, vol. 4, no. 1, pp.72-94. 


\section{NSBM Journal of Management}

Vol. 1, No. 1, January - June, 2015

Van Manen, SM 2014, 'Hazard and risk perception at Turrialba volcano (Costa Rica): implications for disaster risk management', Applied Geography, vol. 50, pp.63-73.

Mansor, S, Shariah, MA, Billa, L, Setiawan, I \& Jabar, F 2004, 'Spatial technology for natural risk management', Disaster Prevention and Management, vol. 13, pp.364-373.

Manyena, SB, O'Brien, G, O'Keefe, P \& Rose, J 2011,'Disaster resilience: a bounce back or bounce forward ability?', Local Environment, vol. 5, no. December, pp.417-424.

Manyena, SB 2006, 'Rural local authorities and disaster resilience in Zimbabwe', Disaster Prevention and Management, vol. 15, pp.810-820.

Mayunga, JS 2007, Understanding and applying the concept of community disaster resilience: a capital-based approach, viewed 07 December 2014, http://www.ihdp.unu.edu/file/get/3761.pdf.

Minamoto, Y 2010, 'Social capital and livelihood recovery: post-tsunami Sri Lanka as a case', Disaster Prevention and Management, vol. 19, pp.548-564.

Mudalige, J 2011, Comprehensive study of existing flood management system in Japan and Sri Lanka, Kobe, Hyogo, viewed 07 December 2014, http://www.adrc.asia/aboutus/vrdata/finalreport/janaki2011_ fr.pdf.

Norris, FH, Stevens, SP, Pfefferbaum, B, Wyche, KF \& Pfefferbaum, RL 2008, 'Community resilience as a metaphor, theory, set of capacities, and strategy for disaster readiness', American Journal of Community Psychology, vol. 41, pp.127-150.

O’Brien, G, O'Keefe, P, Gadema, Z \& Swords, J 2010, 'Approaching disaster management through social learning', Disaster Prevention and Management, vol. 19, pp.498-508.

Obrist, B, Pfeiffer, C \& Henley, R 2010, 'Multi-layered social resilience: a new approach in mitigation research', Progress in Development Studies, vol. 10, pp.283-293.

Ou-Yang, B, Chu, C, Da, Y, Liu, X \& Zhang, H 2015, 'Highway flood disaster risk evaluation and management in China', Natural Hazards, vol. 75, no. S, pp.381-397.

Palliyaguru, R, Amaratunga, D \& Baldry, D 2014, 'Constructing a holistic approach to disaster risk reduction: the significance of focusing on vulnerability reduction', Disasters, vol. 38, pp.45-61.

Pathirage, C, Seneviratne, K, Amaratunga, D \& Haigh, R 2012, 'Managing disaster knowledge: identification of knowledge factors and challenges', International Journal of Disaster Resilience in the Built Environment, vol. 3, no. 3, pp.237-252.

Paton, D \& Johnston, D 2006, 'Disaster resilience: building capacity to co-exist with natuaral hazards and their concequences', Disaster resilience: an integrated approach, Springfield, Charles C. Thomas Publisher, pp. 3-10.

Paton, D, Millar, M \& Johnston, D 2001, 'Community resilience to volcanic hazard consequences', Natural Hazards, vol. 24, pp.157-169.

Pfefferbaum, BJ, Reissman, DB, Pfefferbaum, RL, Klomp, RW \& Gurwitch, RH 2007, 'Building resilience to mass trauma events', Handbook of Injury and Violence Prevention, pp. 347-358.

Quarantelli, EL 1988, 'Disaster studies: an analysis of the social historical factors affecting the development of research in the area', International Journal of Mass Emergencies and Disasters, vol. 5. 
Quarantelli, EL 1998, What is a disaster? A dozen perspectives on the question, Routledge, pp. 13-19. Quarantelli, EL 2000, 'Emergencies, disaster and catastrophes are different phenomena', DRC Preliminary Paper, vol. 304, pp.1-5.

Ranasinghe, H 2011, 'Towards disaster resilient cities in Sri Lanka', Proceedings of International Conference on Building Resilience 2011: Interdisciplinary approaches to disaster risk reduction, and the development of sustainable communities and cities, Kandalama, Sri Lanka.

Roosli, R \& O’Brien, G 2011, 'Social learning in managing disasters in Malaysia', Disaster Prevention and Management, vol. 20, pp.386-397.

Saldana-Zorrilla, SO 2015, 'Assessment of disaster risk management strategies in Argentina', Disaster Prevention and Management, vol. 24, no. 2, pp.230-248.

Scolobig, A, Prior, T, Schröter, D, Jörin, J \& Patt, A 2015, 'Towards people-centred approaches for effective disaster risk management: balancing rhetoric with reality', International Journal of Disaster Risk Reduction, pp.1-11.

Senanayake, DL \& Barthelot, KS 2013, 'Participatory flood mapping and community awareness by school children of Batticaloa city, Sri Lanka', Proceedings of the Resilient Cities 2013 Congress, Bonn, Germany: ICLEI.

Somasundaram, D \& Sivayokan, S 2013, 'Rebuilding community resilience in a post-war context: developing insight and recommendations - a qualitative study in Northern Sri Lanka', International journal of mental health systems, vol. 7, no. 1, p.3.

Stark, E \& Erickson, KT 1978, 'Everything in its path: destruction of community in the buffalo creek flood', Contemporary Sociology, vol. 7, p.421.

Sudmeier-Rieux, K, Jaboyedoff, M \& Jaquet, S 2013, 'Operationalizing "resilience” for disaster risk reduction in mountainous Nepal', Disaster Prevention and Management, vol. 22, pp.1-11.

Thanurjan, R \& Seneviratne, LDIP 2009, 'The role of knowledge management in post-disaster housing reconstruction', Disaster Prevention and Management, vol. 18, no. 1, pp.66-77.

Todd, D \& Todd, H 2011, Natural disaster response, viewed 2 December 2015, http://ieg.worldbank. org/Data/reports/eval_brief_nat_disaster_response.pdf.

Tugade, MM \& Fredrickson, BL 2004, 'Resilient individuals use positive emotions to bounce back from negative emotional experiences', Journal of personality and social psychology, vol. 86, no. 2, pp.320-333.

UNISDR 2005, Hyogo Framework for Action, Hyogo, Japan, viewed 14 December 2014, http://www. unisdr.org/2005/wcdr/intergover/official-doc/L-docs/Hyogo-framework-for-action-english.pdf.

UNISDR 2007, Terminology, viewed12 January 2015, http://www.unisdr.org/we/inform/terminology.

University of Salford \& DMC Sri Lanka 2012, How local governments reducing disaster, viewed 15 December 2014, http://www.salford.ac.uk/_data/assets/pdf_file/0005/394475/How-LocalGovernments-Reducing-Disaster-Risks.pdf.

Vink, K \& Takeuchi, K 2013, 'International comparison of measures taken for vulnerable people in disaster risk management laws', International Journal of Disaster Risk Reduction, vol. 4, pp.63-70. 


\section{NSBM Journal of Management}

Vol. 1, No. 1, January - June, 2015

Walker, B, Holling, CS, Carpenter, SR \& Kinzig, A 2004, 'Resilience, adaptability and transformability in social - ecological systems', Ecology and Society, vol. 9, no. 2, viewed 10 December 2015, http:// fiesta.bren.ucsb.edu/ gsd/resources/courses/Walker.pdf.

World Health Organization (WHO) 2002, Disasters and emergencies - Definitions, viewed 15 Dec 2014, http://apps.who.int/disasters/repo/7656.pdf.

Wickramaratne, S, Ruwanpura, J, Ranasinghe, U, Walawe-Durage, S, Adikariwattage, V \& Wirasinghe, S C 2012, 'Ranking of natural disasters in Sri Lanka for mitigation planning', International Journal of Disaster Resilience in the Built Environment, vol. 3, no. 2, pp.115-132.

Yoshitani, J, Takemoto, N \& Merabtene, T 2007, Factor analysis of water-related disasters in Sri Lanka, Ibaraki-Ken, viewed 14 December 2014, http://www.icharm.pwri.go.jp/publication/pdf/ pdf_0706/sri_e.pdf 